[Agr. Biol. Chem., Vol. 27, No. 10, p. 684 688, 1963]

\title{
Studies on Nicotinoids as an Insecticide
}

\section{Part IV ${ }^{1)}$. Relation of Structure to Toxicity of Pyridylmethylamines*}

\author{
By Hideo Kamimura, Akiyoshi Matsumoto,** Yoshiro MiYazaki** \\ and Izuru Yамамото \\ Laboratory of Pesticide Chemistry, Department of Agricultural Chemistry, Tokyo University of \\ Agriculture, Setagaya-ku, Tokyo. **Seikgaku Kogyo Co., Ltd. \\ Received June 3, 1963
}

\begin{abstract}
3-Pyridylmethylamines, such as 3-pyridylmethyl-N-diethylamine, N-(3-pyridylmethyl)-piperidine and 3-pyridylmethyl-N-dimethylamine provided with the essential moiety of nicotinoids molecule, show comparable toxicity to nicotine against house flies.

3-Pyridylmethylamine without substituent on amino-nitrogen, N-(3-pyridylmethyl)-morpholine having low basic nitrogen, 4-pyridylmethyl-N-diethylamine not provided with proper $\mathrm{N}-\mathrm{N}$ distance and some nicotine-methiodides having quaternary nitrogen show low or no toxicity.

These data support our proposition ${ }^{1)}$ that the essential moiety of nicotinoids molecule responsible for high toxicity is 3-pyridylmethylamine grouping.
\end{abstract}

Studies on the relation of nicotinoids structure to toxicity against insects in a previous paper $^{1)}$ revealed that the essential moiety of nicotinoids structure responsible for high toxicity is chain should have high basicity $\left(\mathrm{pKa}_{1}{ }^{\prime}>7.4\right)$. It can be said that all nicotinoids of high toxicity have the essential moiety in structure, whereas all nicotinoids not provided with the essential moiety are of low or no toxicity.

An important point suggested from the above information is that nicotine structure may be reduced to less complex and more accessible structure, maintaining its toxicity. Some simple compounds were, therefore, prepared to test this idea.

The factors taken into consideration on designing toxic molecules before their syn-

1) Part I, I. Yamamoto et al., This Journal, 26, 709 (1962).

* Comm. on Oct. 27, 1962 at the meeting of the Agricultural Chemical Society of Japan. theses were as follows.

(1) The presence of pyridine ring. Compounds, having some features of nicotine but having no pyridine ring, are of low or no toxicity ${ }^{1}$.

(2) Highly basic nitrogen should be present at the distance of about $4 \AA$ from pyridyl nitrogen ${ }^{1)}$. This nitrogen is protonated in insect body and will anchor the molecule to the anionic site of nervous receptor.

(3) This nitrogen should not be quaternary one, as ionic compounds may penetrate difficultly through the outer cuticle and the ion barrier ${ }^{2)}$ around synaptic region. Indeed, low toxicity of nicotine-methiodides both by injection and by spraying has been reported ${ }^{3)}$. We also confirmed this fact using the authentic nicotine monomethiodide (VIII), isomethiodide (IX) and dimethiodide (X) . 3-

\footnotetext{
2) R.D.O'Brien, “Toxic Phosphorus Esters", Academic Press Inc., 1960 , p. 330 .

3) N. Turner, N. Woodruff, D. Saunders and A. Eisner, Connecticut Agr. Exp. Sta. Bull., 521, (1948), cited by Metcalf, p. 7.
} 
TABle I. Ghemical Structures and NAMES of Compounds used in This EXPeriment

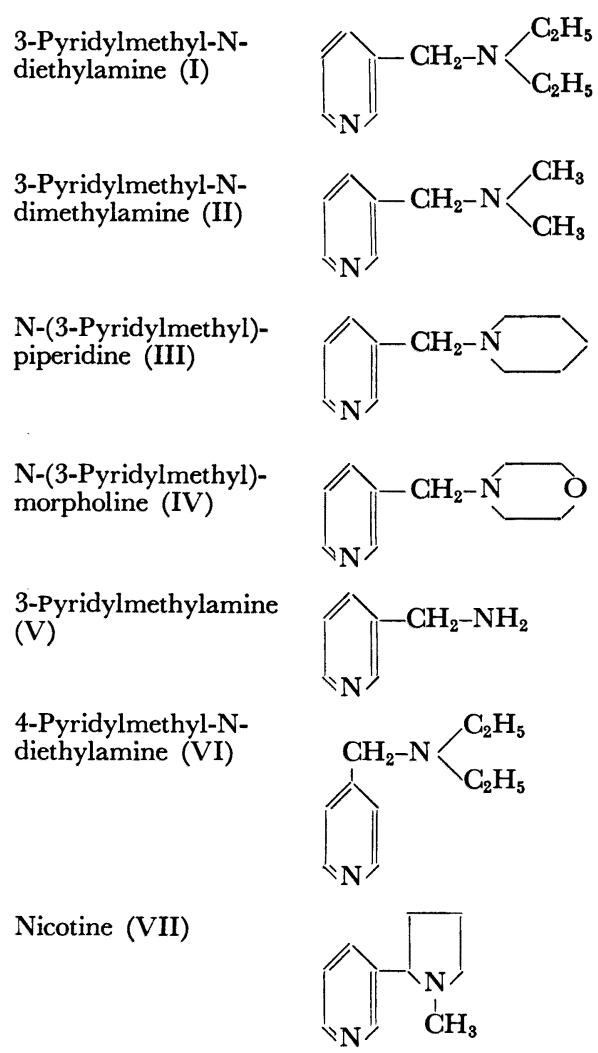

Pyridylmethyl-N-diethylamine dimethiodide (XI) shows also no toxicity by injection (Table III) .

(4) The proper substitution on the above nitrogen. No substitution may perhaps be unprofitable, as acetylcholine analogs without substituent on nitrogen have much less activity than acetylcholine in mammals ${ }^{4}$. Later, 3-pyridylmethylamine (V) was shown to be less toxic than nicotine (Table III) .

(5) No $a$-substituent on pyridine ring. 6Methylnornicotine ${ }^{5)}$ and the other $a$-methylated analogs of biologically active compounds show much decreased activities.

(6) No substituent on the bridge carbon between pyridine ring and amino nitrogen.

\footnotetext{
4) H.R. Ing, Science, 109, 264 (1949).

5) I. Yamamoto and H. Kamimura, This Journal, 27, 445 (1963).
}

Nicotine monomethiodide (VIII)<smiles>C[N+]1(C)CCC1c1ccnnc1</smiles>

Nicotine isomethiodide (IX)<smiles>CN1CCCC1c1cc[n+](C)cc1</smiles>

Nicotine dimethiodide (X)<smiles>C[n+]1ccc([N+]2(C)CCC[N+]2(C)C)cc1</smiles>

3-Pyridylmethyl-Ndiethylamine dimethiodide (XI)<smiles>CC[N+](C)(CC)Cc1ccc[n+](C)c1</smiles>

Metanicotine (XII)<smiles>CNC1=CCCN1</smiles>

Dihydrometanicotine (XIII)<smiles>CNCCc1cccnc1</smiles>

C. H. Richardson and H. H. Shepard ${ }^{6)}$ had shown that 1-(3-pyridyl)-ethyl or -butylamines were of low toxicity.

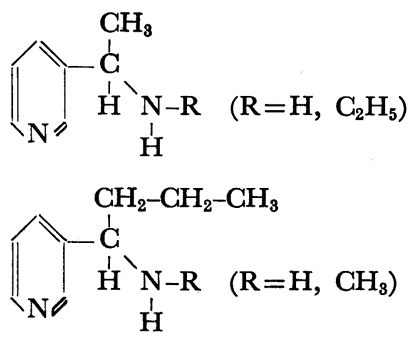

(7) Ease in synthesis.

Some pyridylmethyl-N-disubstituted amines, which are provided with such requirements, were prepared by (a) reducing $\mathrm{N}$-disubsti6) C.H. Richardson and H.H. Shepard, J. Agr. Research, 40, 1007
$(1930)$. 
TABLE II. TOXICITY AND BASICITY OF PYRIDYLMETHYLAMINES

$\begin{array}{crcc}\text { Compounds } & \begin{array}{r}\text { Basicity } \\ \mathrm{pKa}^{\prime}\end{array} & \begin{array}{c}\text { \% of ionized } \\ \text { form at } \mathrm{pH} 7\end{array} & \begin{array}{c}\text { Relative toxicity } \\ \text { (house fly) }\end{array} \\ \text { VII } & 7.9 & 88.8 & 1.0 \\ \text { I } & 8.4 & 96.2 & 2.0 \\ \text { II } & 8.0 & 90.9 & 1.1 \\ \text { III } & 8.4 & 96.2 & 0.9 \\ \text { IV } & 6.0 & 9.1 & <0.1\end{array}$

tuted nicotinamides with lithium aluminum hydride or (b) amination of 3-chloromethylpyridine.

As seen in Table III, 3-pyridylmethyl-Ndiethylamine (I), 3-pyridylmethyl-N-dimethylamine (II) and N-(3-pyridylmethyl)-piperidine (III) show comparable toxicity to that of nicotine (VII) against house flies, Musca domestica vicina Macquardt.

The statement ${ }^{1)}$ that nicotinoids of high toxicity have highly basic nitrogen (but not quaternarized), whereas those having low basic nitrogen are of low or no toxicity, is also applicable to the case of pyridylmethylamines. As seen in Table II, the pyridylmethylamines of high toxicity have highly basic nitrogen, over $90 \%$ of all molecules being protonated at $\mathrm{pH} 7\left(25^{\circ} \mathrm{C}\right)$, whereas $\mathrm{N}$-(3-pyridylmethyl)morpholine (IV) having low basic nitrogen is protonated only by $9 \%$ at $\mathrm{pH} 7\left(25^{\circ} \mathrm{C}\right)$ and shows only slight toxicity.

4-Pyridylmethyl-N-diethylamine (VI), metanicotine(XII) and dihydrometanicotine(XIII), which are not provided with proper N-N distance (factor 2), show also low toxicity (Table III) .

From the structure-insecticidal action relationship in nicotinoids and in pyridylmethylamines, 3-pyridylmethylamine grouping<smiles>CN(C)c1cccnc1</smiles>

( $\mathrm{N}$ in side chain should be

highly basic) may be regarded as a new toxophore.

\section{EXPERIMENTAL}

\section{Chemical Section.}

Preparation of $\mathrm{N}$-diethylnicotinamide from nicotinic acid and diethylamine with phosphorus pentoxide in one step was described by $\mathrm{Saha}^{7)}$. We employed this method for preparing the following three pyridinecarboxamides with good yield (over $80 \%$ yield) .

N-Pyridylcarbonylpiperidine. Piperidine (25 g) was added carefully to nicotinic acid $(25 \mathrm{~g})$ in dried xylene $(80 \mathrm{ml})$. The mixture was cooled in ice and phosphorus pentoxide $(43.2 \mathrm{~g})$ was added in small portions with shaking. The mixture was heated for one $\mathrm{hr}$. to $120^{\circ} \mathrm{C}$ followed by four hr. at $140 \sim 150^{\circ} \mathrm{C}$. After cooling, the reaction mixture was dissolved in water $(60 \mathrm{ml})$ and made alkaline with $25 \%$ sodium hydroxide solution, then extracted with benzene. The residual oil from benzene evaporation was distilled to give $32.5 \mathrm{~g}$ (yield, $84.2 \%$ ). B.p, $175 \sim 176^{\circ} \mathrm{C} / 8 \mathrm{~mm}$ $\left(310^{\circ} \mathrm{C}^{8)}\right) \cdot n_{\mathrm{D}}^{27} \quad 1.5420$. Picrate, m.p. $131 \sim 132^{\circ} \mathrm{C}$ from acetone.

N-Pyridylcarbonylmorpholine. B.p. $\quad 193 \sim 194^{\circ} \mathrm{C} / 8$ $\mathrm{mm}\left(192^{\circ} \mathrm{C} / 6 \mathrm{~mm}^{\theta)}\right) . n_{\mathrm{D}}^{20}$ 1.5525. Picrate, m.p. 174 $175^{\circ} \mathrm{C}$ from acetone $\left(174 \sim 175^{\circ 9)}\right)$.

N-Diethylisonicotinamide. B.p. $155 \sim 157^{\circ} \mathrm{C} / 10 \mathrm{~mm}$ $\left(119 \sim 120^{\circ} \mathrm{C} / 1 \mathrm{~mm}^{10)}\right) . \quad n_{\mathrm{D}}^{18} \quad 1.5157 \quad\left(n_{\mathrm{D}}^{20} \quad 1.525^{10)}\right)$. Picrate, m.p. $175 \sim 176^{\circ} \mathrm{C}$.

N-Dimethylnicotinamide. Prepared by the method of Samejima ${ }^{11)}$ from phenyl nicotinate and aqueous dimethylamine. B.p. $132 \sim 134^{\circ} \mathrm{C} / 6 \mathrm{~mm} \quad\left(103 \sim 104^{\circ} \mathrm{C} /\right.$ $1 \mathrm{~mm}^{11)}$ ). M.p. $38 \sim 45^{\circ} \mathrm{C}$. Picrate, m.p. $148 \sim 150^{\circ} \mathrm{C}$.

Reduction of $\mathrm{N}$-diethylnicotinamide to 3-pyridylmethyl-N-diethylamine (I) with lithium aluminum hydride was first reported by Uffer and Schlittler ${ }^{12}$, later it was improved by Mićović and Mihailović ${ }^{13)}$. We employed essentially the same procedure as that of Mićović and Mihailović for the preparation of other pyridylmethylamines. The infrared spectra of the pyridylmethylamines obtained showed the disappearance of the carbonyl bands in the amides, maintaining the bands characteristic to pyridine ring. Yields, however, were not satisfactory.

\footnotetext{
7) S.K. Saha, J. Indian Chem. Soc., Ind. and News Ed. 19, 165 (1956).

8) Ges. f. chem. Ind. Basel, D.R.P., $351085 ; 441707$.

9) Fabr. Prod. Chimie Org. Laire, Fr. addn., 824,042 (1938).

10) G. Carrara, U.S. patent, 2,858,317, Oct. $28,1958$.

11) M. Samejima, J. Pharm. Soc. Japan, 80, 1706 (1960)

12) A. Uffer and E. Schlittler, Helv. Chem. Acta, 31, 1397 (1948).

13) V.M.Mićović and M.Lj. Mihailović, J. Org. Chem., 18, 1190 (1953).
} 
N-(3-Pyridylmethyl)-piperidine (III). The powdered lithium aluminum hydride $(3.0 \mathrm{~g})$ was suspended in dried ether $(300 \mathrm{ml})$. To the stirring and gently boiling suspension, the solution of $\mathrm{N}$-pyridylcarhonylpiperidine $(30 \mathrm{~g})$ in dried ether $(200 \mathrm{ml})$ was added from the dropping-funnel within twenty-five min. Stirring and heating were continued for another one hr. The mixture was then cooled in an ice-bath and the reaction product and excess of hydride were decomposed by dropwise addition of water (10 $\mathrm{ml}$ ) followed by $10 \%$ sodium hydroxide $(14 \mathrm{ml})$. After vigorous stirring for another twenty min., the mixture was filtered with suction, and the granular precipitate was washed thoroughly with ether. After drying over anhydrous sodium sulfate, the combined ethereal solutions were evaporated and the residual oil was distilled to give $18.7 \mathrm{~g}$ (yield, 68\%). B.p. $123 \sim 123.5^{\circ} \mathrm{C} / 8 \mathrm{~mm}$. $\quad n_{\mathrm{D}}^{20} 1.5205$. UV: $\lambda_{\max }^{\mathrm{MeOH}} 261 \mathrm{~m} \mu$. $\mathrm{pKa}_{1}^{\prime}$ 8.4, $\mathrm{pKa}_{2}^{\prime} 3.2\left(25^{\circ} \mathrm{C}\right)$. Picrate, m.p. $172 \sim 173^{\circ} \mathrm{C}$ from acetone. Anal. Found: C, 44.19; H, 3.95; N, 17.64 . Calcd. for $\mathrm{C}_{11} \mathrm{H}_{10} \mathrm{~N}_{2} \cdot 2 \mathrm{C}_{6} \mathrm{H}_{3} \mathrm{O}_{7} \mathrm{~N}_{3}: \mathrm{C}, 43.54 ; \mathrm{H}, 3.49 ; \mathrm{N}$, $17.65 \%$. Other fractions: b.p. $27 \sim 30^{\circ} \mathrm{C} / 10 \sim 14 \mathrm{~mm}$, $2.9 \mathrm{~g}$, identified as piperidine; b.p. $112 \sim 128^{\circ} \mathrm{C} / 3 \mathrm{~mm}$, $1.3 \mathrm{~g}$, identified as 3-pyridylcarbinol.

N-(3-Pyridylmethyl)-morpholine (IV). Prepared by the same procedure as described above. Yield $65 \%$. B.p. $139 \sim 142^{\circ} \mathrm{C} / 11 \mathrm{~mm} . \quad n_{\mathrm{D}}^{21} 1.5236 . \quad \mathrm{UV}: \lambda_{\max }^{\mathrm{MeOH}}$ $261 \mathrm{~m}_{\mu}$. $\mathrm{pKa}_{1}^{\prime}$ 6.0, $\mathrm{pKa}_{2}^{\prime} 3.4\left(25^{\circ} \mathrm{C}\right)$. Picrate, m.p. $217^{\circ} \mathrm{C}$ from acetone. Anal. Found: C, 42.29; $\mathrm{H}, 3.88$; $\mathrm{N}$, 17.24. Calcd. for $\mathrm{C}_{10} \mathrm{H}_{14} \mathrm{ON}_{2} \cdot 2 \mathrm{C}_{6} \mathrm{H}_{3} \mathrm{O}_{7} \mathrm{~N}_{3}$ : C, 41.52; H, 3.16; N, $17.6 \%$.

3-Pyridylmethyl-N-dimethylamine (II). Prepared by the same procedure as described above. Yield $66 \%$. B.p. $72 \sim 75^{\circ} \mathrm{C} / 3 \mathrm{~mm}$. $n_{\mathrm{D}}^{20}$ 1.4952. UV: $\lambda_{\max }^{\mathrm{MeOH}} 261 \mathrm{~m} \mu$. $\mathrm{pKa}_{1}^{\prime}$ 8.0, $\mathrm{pKa}_{2}^{\prime} 3.3\left(25^{\circ} \mathrm{C}\right)$. Picrate, m.p. $189 \sim 190^{\circ} \mathrm{C}$ from acetone. Anal. Found: C, 40.32; H, 3.27; N, 18.69 . Calcd. for $\mathrm{C}_{8} \mathrm{H}_{12} \mathrm{~N}_{2} \cdot 2 \mathrm{C}_{6} \mathrm{H}_{3} \mathrm{O}_{7} \mathrm{~N}_{3}: \mathrm{C}, 40.43 ; \mathrm{H}, 3.05 ; \mathrm{N}$, $18.85 \%$.

4-Pyridylmethyl-N-diethylamine (VI). Prepared by the same procedure as described above. Yield 50\%. B.p. $101 \sim 103^{\circ} \mathrm{C} / 5 \mathrm{~mm}$. $n_{\mathrm{D}}^{17} 1.4943$. UV: $\lambda_{\max }^{\mathrm{MeOH}} 256$ $\mathrm{m}_{\mu}$. $\mathrm{pKa}_{1}{ }^{\prime} 8.0, \mathrm{pKa}_{2}^{\prime} 3.6\left(25^{\circ} \mathrm{C}\right)$. Picrate, m.p. $175 \sim$ $177^{\circ} \mathrm{C}$ from acetone. Anal. Found: $\mathrm{C}, 42.77 ; \mathrm{H}, 3.81$; $\mathrm{N}$, 18.16. Calcd. for $\mathrm{C}_{10} \mathrm{H}_{10} \mathrm{~N}_{2} \cdot 2 \mathrm{C}_{6} \mathrm{H}_{3} \mathrm{O}_{7} \mathrm{~N}_{3}$ : C, 42.45; $\mathrm{H}, 3.56$; $\mathrm{N}, 18.01 \%$.

4-Pyridylcarbinol (16\%) was also obtained: b.p. 123 $133^{\circ} \mathrm{C} / 5 \mathrm{~mm}$, m.p. $38 \sim 51^{\circ} \mathrm{C} \quad\left(58 \sim 60^{\circ} \mathrm{C}^{14)}\right)$.

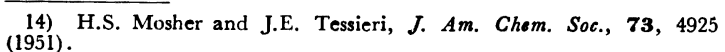

3-Pyridylmethyl-N-diethylamine (I). Prepared by the same procedure as described above. Alternatively, I was prepared by amination of 3-chloromethylpyridine. 3-Chloromethylpyridine-hydrochloride (3 g) (prepared by the method of Mosher and Tessieri14) from pyridylcarbinol with thionyl chloride, the latter being prepared from ethyl nicotinate by reduction with lithium aluminum hydride ${ }^{14)}$ ) was suspended in benzene $(10 \mathrm{ml})$. To the suspension, diethylamine $(5 \mathrm{~g})$ in benzene $(10 \mathrm{ml})$ was added with shaking within a few minutes and the mixture was refluxed for two hr. The reaction mixture was filtered with suction and the precipitate was washed with benzene. The combined benzene solution was evaporated and the residual oil was distilled to give $1.9 \mathrm{~g}(63 \%)$. B.p. $96 \sim 97^{\circ} \mathrm{C} / 3 \mathrm{~mm} \quad\left(108 \sim 109^{\circ} \mathrm{C} / 14 \mathrm{~mm}^{13)}\right) . \quad n_{\mathrm{D}}^{19}$ 1.5059. UV: $\lambda_{\max }^{\mathrm{MeOH}} 261 \mathrm{~m} \mu . \mathrm{pKa}_{1}^{\prime}$ 8.4, $\mathrm{pKa}_{2}{ }^{\prime} 2.8$ $\left(25^{\circ} \mathrm{C}\right)$. Picrate, m.p. $183 \sim 184^{\circ} \mathrm{C}$ from acetone. Anal. Found: $\mathrm{C}, 42.25 ; \mathrm{H}, 3.93 ; \mathrm{N}, 18.30$. Calcd. for $\mathrm{C}_{10} \mathrm{H}_{16} \mathrm{~N}_{2} \cdot 2 \mathrm{C}_{6} \mathrm{H}_{3} \mathrm{O}_{7} \mathrm{~N}_{3}: \mathrm{C}, 42.45 ; \mathrm{H}, 3.56 ; \mathrm{N}, 18.01 \%$.

3-Pyridylmethylamine (V). 3-Pyridylcyanide in methanol was hydrogenated to $V$ by the method of Kolloff $^{15)}$, Huber ${ }^{18)}$ and Adkins ${ }^{17)}$ using Raney nickeJ under hydrogen $\left(90 \sim 70 \mathrm{~kg} / \mathrm{cm}^{2}\right)$. B.p. $94 \sim 95^{\circ} \mathrm{C} / 7$

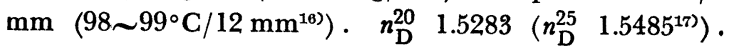
$\mathrm{UV}: \lambda_{\max }^{\mathrm{MeOH}} 262 \mathrm{~m}_{\mu} . \mathrm{pKa}_{1}^{\prime}$ 8.2, $\mathrm{pKa}_{2}^{\prime} 3.2 \quad\left(25^{\circ} \mathrm{C}\right)$. Picrate, m.p. $211^{\circ} \mathrm{C}$ (decomp.) $\left(210 \sim 211^{\circ} \mathrm{C}^{17)}\right)$. Phthalimide, m.p. $153^{\circ} \mathrm{C}$.

Nicotine monomethiodide (VIII) and nicotine isomethiodide (IX) were prepared by the method of Barlow $^{18)}$ and nicotine dimethiodide (X) by that of Späth ${ }^{18)}$.

Nicotine Monomethiodide (VIII). Sintered from $93^{\circ} \mathrm{C}$, melted at $115^{\circ} \mathrm{C}$. Anal. Found: I, 41.2. Calcd. for $\mathrm{C}_{11} \mathrm{H}_{17} \mathrm{~N}_{2} \mathrm{I}$ : I, $41.7 \%$. Monohydrate, sintered from $72^{\circ} \mathrm{C}$, melted at $89^{\circ} \mathrm{C}$ (sintered at $73^{\circ} \mathrm{C}$ and melted at $\left.89^{\circ} \mathrm{C}^{18)}\right)$. UV: $\lambda_{\max }^{\mathrm{H}_{2} \mathrm{O}} \quad 226$ and $260 \mathrm{~m}_{\mu} \quad(225$ and 260 $\mathrm{m} \mu^{18)}$ ). IR (Nujol): 1589 and $1574 \mathrm{~cm}^{-1}$ (pyridine ring vibration).

Nicotine Isomethiodide (IX). M.p. $162^{\circ} \mathrm{C}$ from ethanol, acetone and ether mixture $\left(161^{\circ} \mathrm{C}^{18)}\right)$. Anal. Found: I, 42.2. Calcd. for $\mathrm{C}_{11} \mathrm{H}_{17} \mathrm{~N}_{2} \mathrm{I}: \mathrm{I}, 41.7 \%$. UV: $\lambda_{\max }^{\mathrm{H}_{2} \mathrm{O}} \quad 224$ and $263.5 \mathrm{~m}_{\mu} \quad\left(224\right.$ and $\left.264 \mathrm{~m}_{\mu^{18)}}\right)$. IR (Nujol) : $1638 \mathrm{~cm}^{-1} \quad(\mathrm{C}=\stackrel{+}{\mathrm{N}}$ in pyridine ring).

15) H.G. Kolloff and J.H. Hunter, ibid., 63, 490 (1941).

16) W. Huber, ibid., 66, 876 (1944).

17) H. Adkins, I.A. Wolff, A. Pavlic and E. Hutchinson, ibid., 66, 1293 (1944).

18) R.B. Barlow and N.A. Dobson, J. Pharm. Pharmacol., 7, 27 (1955). 
Nicotine Dimethiodide (X). M.p. $219 \sim 220^{\circ} \mathrm{C}$ from methanol $\left(220^{\circ} \mathrm{C}^{19)}\right)$. Anal. Found: I, 57.3. Calcd. for $\mathrm{C}_{12} \mathrm{H}_{20} \mathrm{~N}_{2} \mathrm{I}_{2}: \mathrm{I}, 56.9 \%$. UV: $\lambda_{\max }^{\mathrm{H}_{2} \mathrm{O}} 226$ and $262 \mathrm{~m}_{\mu}$. IR (Nujol): $1638 \mathrm{~cm}^{-1}(\mathrm{C}=\stackrel{+}{\mathrm{N}}$ in pyridine $\mathrm{ring})$.

3-Pyridylmethyl-N-diethylamine Dimethiodide (XI). Prepared from the amine and excess methyl iodide in methanol. Amorphous solid. Anal. Found: I, 57.1. Calcd. for $\mathrm{C}_{12} \mathrm{H}_{22} \mathrm{~N}_{2} \mathrm{I}_{2}: \mathrm{I}, 56.6 \%$. UV: $\lambda_{\max }^{\mathrm{H}_{2} \mathrm{O}} 226$ and $261.5 \mathrm{~m}_{\mu}$. IR (Nujol) : $1638 \mathrm{~cm}^{-1} \quad(\mathrm{C}=\stackrel{+}{\mathrm{N}}$ in pyridine ring) .

Metanicotine (XII). Prepared by the method of

TABLE III. TOXICITY OF NICOTINE METHIODIDES, PYRIDYLMETHYLAMINES AND THE RELATED COMPOUNDS

$\begin{array}{lc}\text { Compounds } & \text { M. domestica (house fly) } \\ \text { VII } & \text { LG } \% \text { (film method) } \\ \text { I } & 0.87 \\ \text { II } & 0.43 \\ \text { III } & 0.79 \\ \text { IV } & 0.93 \\ & >8.7 \\ \text { VII } & \text { Mortality \% at } \% \text { toxi- } \\ \text { V } & \text { cant (film method) } \\ \text { VI } & 100 \\ & 10 \\ & 33 \\ \text { VII } & \% \text { at } 40 \mu \mathrm{g} / \\ \text { VIII } & \text { Mortality } \% \\ \text { IX } & \text { female fly fly after } 24 \mathrm{hr} . \\ \text { X } & \text { (injection method) } \\ \text { XI } & 100 \\ & 0 \\ \text { VII } & 0 \\ \text { XII } & 0 \\ \text { XIII } & 0 \\ \text { V } & 100 \\ & \text { Mortality } \% \text { at } 1 \% \text { toxicant }\end{array}$

19) E. Späth und G. Bobenberger, Ber., 77, 362 (1944).
Löffler and $\mathrm{Kober}^{20)}$. B.p. $121 \sim 122^{\circ} \mathrm{C} / 3 \mathrm{~mm}, 270 \sim$ $273^{\circ} \mathrm{C}\left(272 \sim 274^{\circ} \mathrm{C}^{20)}\right)$. Picrate, m.p. $171^{\circ} \mathrm{C}\left(171^{\circ} \mathrm{C}^{211}\right)$.

Dihydrometanicotine (XIII). Metanicotine was hydrogenated by the method of Löffler and Kober ${ }^{20)}$. B.p. $133 \sim 135^{\circ} \mathrm{C} / 10 \mathrm{~mm} \quad\left(131 \sim 132^{\circ} \mathrm{C} / 8 \mathrm{~mm}^{20)}\right)$. Picrate, m.p. $162 \sim 163^{\circ} \mathrm{C} \quad\left(161 \sim 162^{\circ} \mathrm{C}^{20)}\right)$.

\section{Biological Section.}

The insecticidal actions of the pyridylmethylamines by a film method and of the methiodides by an injection method to house flies were summarized in Table III.

The film method is essentially the same as described in a previous paper ${ }^{1)}$. The injection was carried out by injecting $1 \mu \mathrm{l}$ of $4 \%$ aqueous solution of toxicant into the mesonopum of a house fly.

The toxicity of 3-pyridylmethyl-N-diethylamine (PDEN) (I) to mouse, which was tested by Professor Ueda, was summarized in Table IV, comparing with other toxicants.

TABLE IV. TOXICITY OF 3-PYRIDYLMETHYL-NDIETHYLAMINE (PDEN) (I) AND OTHER TOXICANTS TO MOUSE

$\begin{array}{lcc}\text { Compounds } & \text { Oral } & \begin{array}{c}\mathrm{LC}_{50} \mathrm{mg} / \mathrm{kg} \\ \text { cutaneous }\end{array} \\ \text { TEPP } & 3 & 8 \\ \text { DDVP } & 71 & 206 \\ \text { PDEN (I) } & 445 & 1050 \\ \text { Allethrin } & 445 & 1200 \\ \text { Malathion } & 570 & 2330\end{array}$

Acknowlegement. We wish to express our thanks to Professor Ryo Yamamoto, Tokyo University of Agriculture, for his constant encouragement, and also to Professor Kiichi Ueda, Tokyo Dental College, for carring out toxicity tests to mouse.

20) K. Löffler und S. Kober, ibid., 42, 3431 (1909).

21) A. Pinner, ibid., 27, 1058, 2863 (1894). 